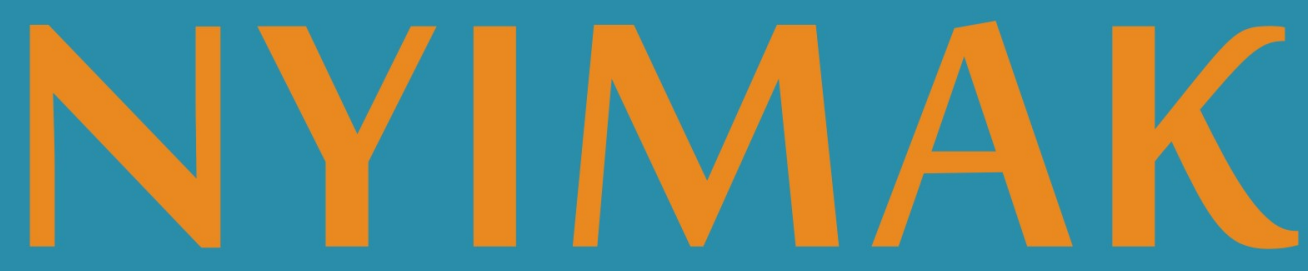

\title{
Journal of Communication
}

Nyimak Journal of Communication | Vol. 3 | No. 1 | Halaman 1 - 96 | Maret 2019| ISSN 2580-3808

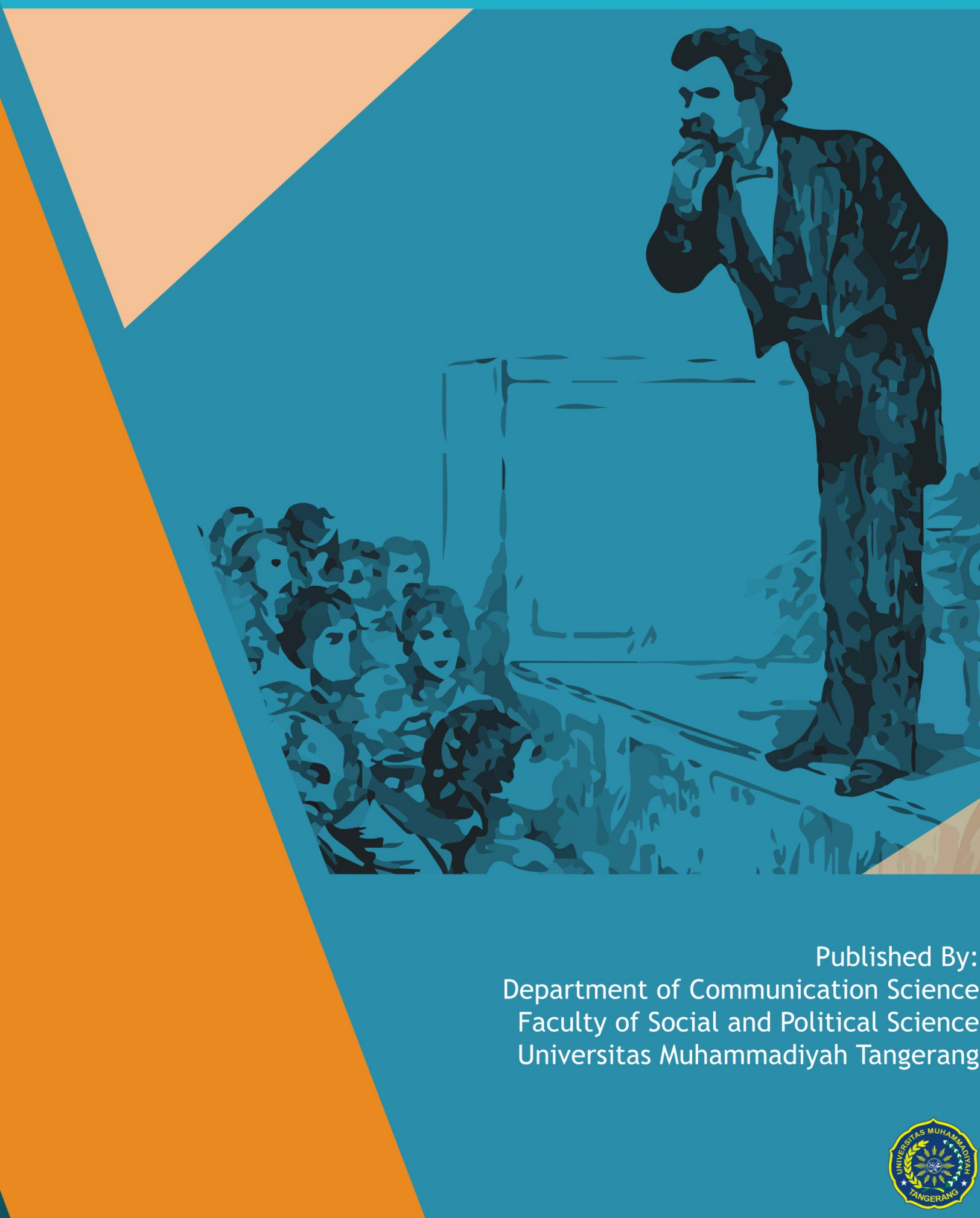




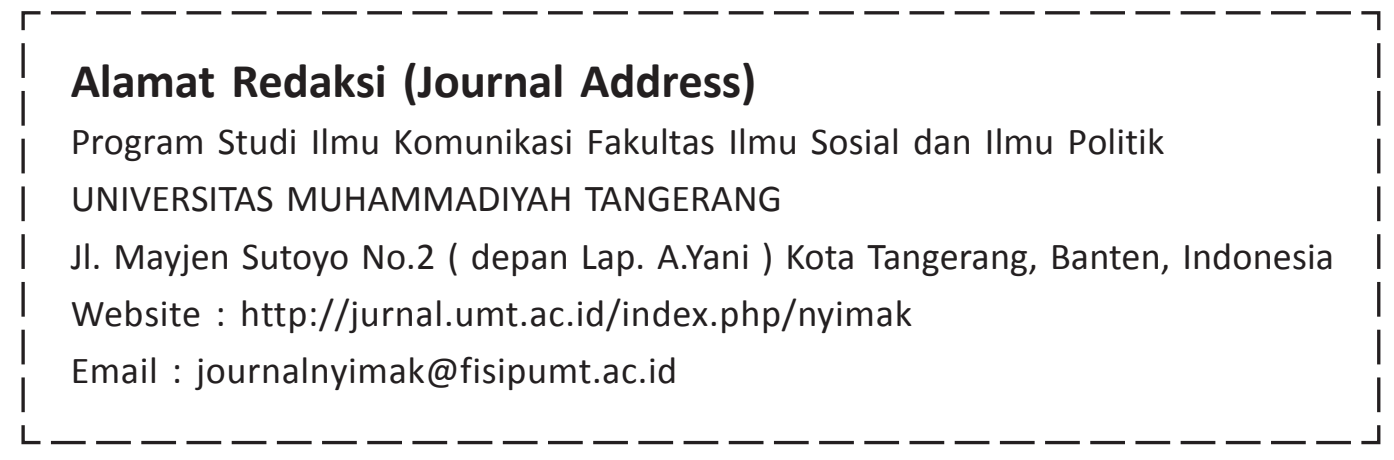




\section{NYIMAK Journal of Communication}

\section{DAFTAR ISI (TABLE OF CONTENT)}

Media Sosial dan Munculnya Gejala Sosiopat di Kalangan Mahasiswa -Nurudin-

Komodifikasi Konten, Khalayak, dan Pekerja pada Akun Instagram @salman_al_jugjawy

— Sigit Surahman, Annisarizki \& Rully-

Tabloidisasi Pertikaian Selebriti dalam Tayangan Infotainment "PagiPagi Pasti Happy"

—Ardiska Mega Perwita \& Filosa Gita Sukmono- 


\title{
Penggunaan Bahasa Korea (Hangeul) dalam Instagram sebagai Bentuk Presentasi Diri
}

\author{
Annisa Nurul Mardhiyah \\ Program Studi IImu Komunikasi Fakultas Komunikasi dan Bisnis Universitas Telkom \\ Email: annisanurulmardhiyah@gmail.com \\ Ayub Ilfandy Imran \\ Program Studi IImu Komunikasi Fakultas Komunikasi dan Bisnis Universitas Telkom \\ Email: a_ilfandy@yahoo.com
}

\begin{abstract}
ABSTRAK
Korean wave merupakan perpaduan antara budaya tradisional Korea Selatan dengan budaya pop yang disajikan dalam bentuk drama ( $K$-drama) dan musik ( $K$-pop). Korean wave telah menarik perhatian masyarakat dari berbagai negara dan menjadi salah satu budaya populer yang mampu bersaing dengan budaya Barat. Penelitian ini bertujuan mengetahui bagaimana presentasi diri pengguna Instagram ketika menggunakan bahasa Korea (Hangeul). Penelitian ini menggunakan paradigma konstruktivisme dan pendekatan kualitatif. Hasil penelitian menunjukkan bahwa para informan yang terlibat dalam penelitian ini mempelajari Hangeul secara otodidak serta memiliki motivasi yang sama dalam mempelajari Hangeul, yaitu merasa tertarik dengan dunia hiburan dan budaya Korea. Mereka lalu menjadikan Instagram sebagai ruang presentasi diri melalui penggunaan Hangeul. Ekspektasi yang diharapkan adalah munculnya kesan bahwa mereka adalah sosok yang mengagumkan karena menguasai bahasa asing (Korea), mirip dengan orang Korea asli, dapat menunjukkan identitas sebagai penggemar idola Korea, dan menunjukkan bahwa kegiatan fan girling mempunyai sisi positif.
\end{abstract}

Kata Kunci: Dramaturgi, presentasi diri, Instagram, Hangeul

\begin{abstract}
The Korean wave is a blend of traditional South Korean culture with pop culture presented in the form of drama (K-drama) and music (K-pop). The Korean wave has attracted the attention of people from various countries and has become one of the popular culture that is able to compete with Western culture. This study aims to find out how self-presentation of Instagram users when using Korean (Hangeul). This study uses constructivism paradigm and qualitative approach. The results showed that the informants involved in this study studied Hangeul in a self-taught manner and had the same motivation in learning Hangeul, which felt interested in the world of entertainment and Korean culture. They make Instagram as a self presentation space through the use of Hangeul. What is expected is the emergence of the impression that they are amazing figures because they master foreign languages (Korean), similar to native Koreans, can show their identity as fans of Korean idols, and show that the girling fan activities have a positive side.
\end{abstract}

Keywords: Dramaturgi, self disclosure, Instagram, Hangeul

Citation: Mardhiyah, Annisa Nurul dan Ayub Ilfandy Imran. (2019). “Penggunaan Bahasa Korea (Hangeul) dalam Instagram sebagai Bentuk Presentasi Diri". Nyimak Journal of Communication, 3(1): 61-75. 


\section{PENDAHULUAN}

Budaya (bahasa Sanskerta: buddhayah) merupakan sesuatu yang dimiliki secara bersama oleh sebuah kelompok dan diwariskan secara turun-temurun. Kebudayaan yang dianut sebuah kelompok tentunya akan memengaruhi perilaku kelompok tersebut, yang meliputi cara berpikir, cara merasa, dan cara berbuat. Selain itu, kebudayaan memegang peran yang sangat penting dalam menentukan perilaku serta gaya hidup suatu kelompok secara menyeluruh. Kebudayaan terbagi atas dua macam, yakni kebudayaan tinggi (elite culture) dan kebudayaan populer (pop culture). Kebudayaan tinggi merupakan hasil dari pemikiran kaum-kaum elit menyangkut pengetahuan, pola pikir serta nilai yang dianut masyarakat dan dijadikan sebagai landasan perilaku. Sementara itu, kebudayaan populer merupakan budaya yang erat kaitannya dengan kekuatan dan intensitas media massa dalam memperkenalkan budaya tersebut sehingga dikenal oleh masyarakat. Sekarang ini terdapat salah satu pop culture yang menjadi pusat perhatian di dunia, terutama negara-negara Asia, yaitu budaya Korea Selatan. Kesuksesan Korea Selatan memperkenalkan kebudayaannya ditandai dengan tampilnya istilah The Korean Wave yang menunjukkan besarnya pengaruh kebudayaan Korea Selatan di mana pun, termasuk juga di Indonesia (Ainslie, 2016; Hong \& Kim, 2013; Jeong, Lee \& Lee, 2017; Trolan, 2017; Shim, 2006; Peichi, 2013; Jin \& Yoon, 2017).

Korean Tourism Organization (dalam Bae, et al., 2017) mendefinisikan Korean Wave sebagai sebuah perpaduan antara budaya tradisional Korea Selatan dengan budaya pop yang disajikan dalam bentuk drama (K-drama) dan musik (K-pop) Korea. Budaya Korea dinilai memiliki keunikan tersendiri sehingga mampu menguasai pasar Asia serta menjadi salah satu budaya populer yang mampu bersaing dengan budaya Barat. Korean Wave sendiri menarik perhatian masyarakat dari berbagai negara. Tentunya ada dampak signifikan terhadap ketertarikan masyarakat untuk mengenal hingga mengaplikasikan aspek-aspek budaya Korea Selatan, seperti kuliner, kosmetik, tata busana, adat, dan juga bahasa Korea (Hangeul) hingga pada kesenian (musik) (Dater \& Seo, 2004; Kim, 2017; Sung, 2010).

Meningkatnya eksistensi bahasa Korea di kalangan masyarakat, khususnya para penggemar dunia hiburan Korea Selatan, merupakan salah satu dampak yang signifikan dari fenomena Korean Wave. Para penggemar drama dan musik Korea ini mempelajari bahasa Korea agar dapat mengerti maksud dari drama dan musik yang dinikmati. Korea Selatan merupakan salah satu negara yang menggunakan huruf dengan bentuk yang unik. Korean Wave dengan popularitasnya mampu membuat masyarakat asing tertarik untuk mengenal dan mempelajari bahasa Korea secara mendalam. Untuk hal ini, sangat jelas dibutuhkan kemampuan tersendiri agar mampu membaca dan memahami literatur Korea yang seluruhnya tertulis dalam bentuk Hangeul. Minat terhadap bahasa Korea ini pun dipicu oleh popularitas 
K-Drama, tayangan variety dan reality show serta $K$-Pop yang mampu mendorong penggemarnya untuk mempelajari bahasa Korea (Hangeul). Penulisan bahasa Korea disebut Hangeul, yaitu sebuah sistem simbol yang diciptakan Raja Sejong (1397-1450) dari Dinasti Joseon yang selanjutnya dijadikan sebagai abjad resmi bahasa Korea. Hangeul terdiri dari 10 huruf vokal dan 14 huruf konsonan serta 11 huruf vokal gabungan dan 6 huruf konsonan gabungan; secara keseluruhan terdapat 21 vokal dan 19 konsonan. Penggunaan bahasa Korea juga diterapkan di dalam komunikasi sehari-hari baik dalam bentuk lisan berupa penggunaan istilah-istilah maupun tulisan berupa huruf Hangeul itu sendiri. Fenomena penggunaan huruf Hangeul Korea ini dapat ditemukan dalam komunikasi verbal yang terjadi di media sosial seperti Instagram atau pada media sosial lainnya (Aisyah, 2017; Huang, 2017; Hwang \& Cho, 2018).

Dalam Instagram, pengguna dapat mengunggah foto atau video yang bisa disertai caption untuk menjelaskan perihal foto atau video tersebut; pengguna juga dapat saling berinteraksi dengan pengguna lainnya lewat kolom komentar. Selain itu, Instagram juga menyediakan fitur-fitur kreatif yang bisa menunjang proses interaksi tersebut. Instagram menjadi tempat yang tepat untuk berekspresi dan mempublikasikan hasil karya, di mana citra seorang pengguna bisa terlihat dari feed, foto dan video yang diunggahnya, caption yang ditulis dan bio pada profilnya (Sagiyanto \& Ardiyanti, 2018; Al-Kandari, Melkote \& Sharif, 2016; Bazarova \& Choi, 2014; Kusyanti \& Safitri, 2016).

Sementara itu, penggunaan huruf Hangeul dapat terlihat pada caption yang ditulis oleh pengguna Instagram untuk mendeskripsikan foto yang diunggah atau pada bagian kolom bio untuk mendeskripsikan profil dirinya. Hangeul juga kerap digunakan untuk berkomentar pada akun-akun idola mereka dengan tujuan menyamakan pemahaman pada kalimat yang ingin diutarakan kepada idolanya. Sering kali, pengguna mencampur bahasa Korea dalam bentuk Hangeul dan bentuk bahasa lainnya, misalnya bahasa Latin, Indonesia atau Inggris. Di Korea itu sendiri, budaya dalam bentuk bahasa masih sangat kental sehingga warga asli Korea yang fasih berbahasa Inggris belum banyak. Sebab itu, untuk menulis ungkapan dukungan dan rasa sukanya, para penggemar idola Korea harus menggunakan Hangeul untuk mencapai kesepahaman makna.

Ketika menggunakan Hangeul, para pengguna sering kali hanya memanfaatkan media translasi (seperti Google Translate), karena Hangeul memang bukan bahasa yang mudah untuk dipelajari. Hangeul tidak menggunakan bentuk Latin, melainkan memiliki simbol-simbol bermakna sendiri hingga dibutuhkan usaha yang lebih untuk bisa sekadar memelajari cara baca dan penulisannya. Meski Hangeul merupakan bahasa yang cukup rumit, tapi banyak juga pengguna Hangeul dalam Instagram yang memang mempelajari Hangeul mulai dari 
penulisan, cara baca hingga penataan kalimatnya. Adapun rasa suka mereka terhadap kebudayaan Korea dan dunia hiburan Korea adalah motivasi tersendiri untuk mempelajari Hangeul hingga mahir. Dalam mempelajari Hangeul, para pengguna tersebut menggunakan metode otodidak dengan memanfaatkan silabus-silabus berisi materi pembelajaran Hangeul yang tersedia pada situs-situs internet secara gratis. Tidak hanya dalam bentuk modul tertulis, silabus tersebut juga tersedia di dalam bentuk audio visual yang mampu memudahkan proses belajar mereka.

Ketika seseorang memiliki kemampuan akan sesuatu hal, maka akan timbul rasa bangga pada diri mereka yang akhirnya memicu munculnya rasa ingin menunjukkan kemampuannya kepada orang lain. Dalam mempertunjukkan suatu kemampuan, maka seseorang akan berusaha secara optimal agar mencapai kesan yang diharapkannya. Para pengguna Hangeul di Instagram memilih menampilkan kemampuan mereka lewat cara menulis ungkapan dalam bentuk Hangeul pada caption, bio atau komentar yang mereka tulis, karena Hangeul mempunyai bentuk penulisannya unik dengan simbol tersendiri sehingga akan bisa mudah jika mempertunjukkan kemampuan Hangeul mereka melalui Instagram.

Presentasi diri merupakan hal yang penting, terutama saat berada di dunia maya (Schau \& Gilly, 2003; Williamson, Patricia, et al., 2017; Al-Kandari, Al-Sumait \& Al-Hunaiyyan, 2017; Vainikka, Noppari \& Seppänen, 2017). Pengguna media sosial seperti Instagram akan berusaha menampilkan sisi terbaik untuk menciptakan kesan tersendiri dia benak pengikut akun Instagram mereka dan mencapai citra diri yang diharapkannya. Pemilihan bahasa yang digunakan pengguna dalam Instagram adalah salah satu alat bagi pengguna guna mempresentasikan dirinya. Hal inilah yang kemudian mendasari peneliti guna meneliti terkait bagaimana pengguna Instagram mempresentasikan dirinya melalui bahasa Korea (hangeul) pada media sosial Instagram.

\section{KERANGKA TEORI}

\section{Bahasa}

Bahasa merupakan saluran untuk menyampaikan maksud serta makna tertentu dari satu orang ke orang lainnya. Maksud yang ingin disampaikan oleh pembicara akan dapat dimengerti oleh lawan bicara melalui bahasa yang digunakan. Menurut Chaer dan Agustina (dalam Hayutami, 2012) bahasa punya fungsi utama sebagai alat komunikasi. Soeparno (dalam Hayutami, 2012) juga mengatakan bahwa fungsi umum sebuah bahasa adalah sebagai alat komunikasi sosial. 
Kridalaksana (dalam Hayutami, 2012) mengartikan bahasa sebagai suatu sistem lambang/simbol bunyi yang digunakan masyarakat untuk bekerja sama, berinteraksi dan mengidentifikasi diri. Bahasa menjadi sebuah identitas diri bagi penuturnya; melalui bahasa yang ia tuturkan maka orang lain dapat mengetahui latar budaya yang ia miliki.

Bahasa juga bisa menjadi alat bagi kebudayaan untuk dibentuk, dikembangkan dan diturunkan kepada generasi selanjutnya. Komunikasi menggunakan bahasa tertentu memungkinkan tiap orang untuk menyesuaikan diri dengan lingkungan sekitar. Bahasa memegang peranan penting dalam mengembangkan dan memperkenalkan budaya suatu negara ke negara lainnya, karena bahasa adalah hal yang akan disorot pertama kali saat memperkenalkan suatu budaya.

\section{Media Sosial}

Media merupakan suatu wadah yang disertai teknologi di dalamnya, misalnya koran dan majalah yang berarti media cetak; radio yang berarti media audio, dan televisi yang merupakan bentuk media audio dan visual. Nasrullah (2015) mengatakan bahwa media sosial dapat dipandang sebagai sebuah medium berbasis internet yang berfungsi sebagai alat representasi diri dan berinteraksi, bekerja sama, berbagi dan berkomunikasi bagi penggunanya sehingga mampu untuk membentuk ikatan sosial secara virtual.

Dalam bukunya The Culture of Connectivity: A Critical History of Social Media (2013), Jose van Dijck mendefinisikan media sosial sebagai wadah yang berfokus pada keberadaan pengguna dan mencoba memfasilitasi mereka dalam beraktivitas. Dalam hal ini, media sosial dapat dipandang sebagai medium online yang mampu menghubungkan antarpengguna untuk membangun ikatan sosial. Meikle dan Young (2012) memandang media sosial sebagai suatu hasil konvergensi komunikasi personal (adanya proses saling berbagi antarindividu) dengan media publik yang memiliki motif untuk berbagi kepada siapa pun tanpa ada spesifikasi apa pun. Pengertian tersebut juga senada dengan definisi yang diajukan oleh Kaplan dan Haenlein (2010) yang menyebutkan bahwa media sosial adalah kelompok aplikasi berbasis media internet yang memungkinkan penciptaan serta pertukaran user-generated content.

Salah satu jenis media sosial ialah jejaring sosial (social networking). Nasrullah (2015) menjelaskan bahwa jejaring sosial merupakan salah satu jenis media sosial yang paling populer. Di jejaring sosial, pengguna dapat saling berinteraksi dengan pengguna lainnya; karakteristik utama jejaring sosial adalah pengguna dapat membentuk jaringan pertemanan dengan pengguna lainnya, seperti Instagram yang dapat memfasilitasi para penggunanya untuk dapat berinteraksi dan membagikan foto atau video yang berkesan kepada pengikutnya. 


\section{Presentasi Diri}

Dalam The Presentation of Self in Everyday Life (1959), Goffman menjelaskan bahwa sosok diri bukanlah kepunyaan seseorang, tapi hanya sesuatu yang dipinjamkan oleh orang lain. Mengacu pada teori interaksionisme simbolik, manusia mempelajari bagaimana cara untuk bermain peran dan mengasumsikan identitasnya dengan peran-peran tersebut, hal ini dilakukan dengan terlibat dalam kegiatan pertunjukkan akan siapa dan apa yang mereka perankan. Presentasi diri seseorang bertujuan untuk membentuk situasi dan identitas sosial bagi diri (dalam Saraswati, 2017). Interaksi simbolik sendiri merupakan aktivitas komunikasi atau pertukaran simbol yang memiliki makna tertentu di dalamnya (Mulyana, 2008). Teori ini menjelaskan bahwa individu merespon makna yang mereka bangun selama berinteraksi satu sama lainnya. Terjadinya sebuah interaksi simbolik didasarkan pada gagasan dan hubungan di masyarakat. Setiap individu akan berinteraksi berdasarkan makna yang terdapat pada orang, benda atau peristiwa tertentu. Makna ini diciptakan dari bahasa yang digunakan untuk berkomunikasi dengan orang lain, diri sendiri atau pikirannya.

Saraswati (2017) mendefinisikan presentasi diri sebagai upaya seseorang dalam membentuk suatu kesan ketika sedang berhadapan dengan orang lain. Kesan tersebut dapat dibentuk dengan menata perilakunya sedemikian rupa supaya orang lain mampu memaknai identitas dirinya sesuai dengan apa yang ia inginkan. Selama proses produksi identitas tersebut, seseorang akan melakukan berbagai pertimbangan terhadap atribut yang digunakan, di mana atribut yang ia gunakan haruslah sesuai dan mendukung kesan dan identitas yang ingin ditampilkan. Arrianie (dalam Mulyana, 2008) mengemukakan bahwa seseorang akan berusaha untuk menunjukkan sosok diri yang ideal sesuai dengan status perannya dalam suatu kegiatan. la akan berusaha untuk tidak menunjukkan fakta atau motif yang tidak sesuai dan sejalan dengan citra yang ingin ditampilkannya dalam benak khalayak.

Goffman (1959) berasumsi bahwa pada interaksi yang terjadi di antara individu, masingmasing dari mereka akan menginginkan penyajian gambaran diri yang mampu meninggalkan kesan tertentu setelah interaksi berlangsung. Menurut Adhiatma (2018), presentasi diri merupakan cara individu dalam mengekspresikan dan menunjukkan apa yang ia miliki kepada khalayak dengan melakukan beberapa upaya untuk menciptakan kesan tersendiri di benak khalayak. Goffman memandang presentasi diri sebagai sebuah aktivitas yang dilakukan guna memengaruhi seseorang lewat pertunjukan (performance) seperti ungkapan tersirat, ungkapan bersifat teateris, nonverbal, kontekstual, dan tidak bersifat intensional (Mulyana, 2008).

Peneliti memandang presentasi diri sebagai aksi yang dilakukan individu baik itu secara verbal maupun nonverbal dengan tujuan untuk menciptakan suatu kesan terhadap khalayak. 
Sesuai dengan pemaparan diatas, tentunya seorang individu akan melakukan presentasi diri melalui akun Instagram dengan menunjukkan beberapa hal, misalnya saja dengan bahasa yang digunakan untuk memberikan kesan tertentu pada benak pengguna lainnya.

\section{Dramaturgi}

Presentasi diri erat kaitannya dengan kajian dramaturgi. Fokus dari dramaturgi adalah bagaimana mereka melakukan sesuatu, bukan apa yang ingin dilakukan atau apa yang akan mereka lakukan (Mulyana, 2001). Dramaturgi menekankan kepada dimensi ekspresif dalam aktivitas manusia, di mana makna tentang sesuatu akan tercermin dari cara mereka mengekspresikan diri dalam interaksi dengan orang lain. Di sini, perilaku manusia bersifat ekspresif sehingga manusia itu sendiri bersifat dramatik. Selanjutnya, Goffman (1959) mengatakan bahwa dramaturgi memiliki inti pandangan bahwa dalam interaksi antarindividu, setiap individu ingin mengelola pesan yang berisi makna tersirat untuk mengatur bagaimana individu lain akan memandangnya. Goffman menjelaskan bahwa dalam dramaturgi kehidupan sosial manusia dianalogikan sebagai pertunjukan di atas panggung di mana akan ada aktor yang memainkan peran-peran tertentu.

Kehidupan sosial ini dibagi menjadi panggung depan (front stage), panggung tengah (middle stage) dan panggung belakang (back stage). Selama di panggung depan, individu akan menampilkan peran dengan sebaik mungkin. la bagaikan seorang aktor yang dengan lihai mempraktikkan semua script yang sudah disiapkan sebelumnya. Lalu di panggung tengah, individu melakukan persiapan yang dapat mendukung optimalisasi perannya di depan panggung. Panggung tengah kadang-kadang juga digunakan untuk menampilkan peran sampingan di mana individu menggunakan peran tersebut untuk mendapatkan keuntungan. Sementara itu, pada panggung belakang inilah tempat yang memungkinkan ia untuk mempersiapkan diri sebelum memainkan perann dan menjadi dirinya sendiri (Mulyana, 2001).

\section{METODE PENELITIAN}

Penelitian ini menggunakan paradigma konstruktivisme dan dengan pendekatan kualitatif. Penelitian kualitatif adalah metode eksplorasi dan pemahaman makna dalam masalah sosial atau kemanusiaan oleh individu/kelompok (Cresswell, 2004). Paradigma konstruktivisme merupakan paradigma yang menganalisis aksi sosial lewat pengamatan langsung dan rinci pada pihak yang bersangkutan dalam menciptakan serta mengelola lingkungan sosial mereka (Hidayat, 2003). Dalam penelitian ini, peneliti mengajukan beberapa pertanyaan pada tiga informan kunci, dua orang informan pendukung dan satu ahli dengan arah pertanyaan yang bersifat terbuka. Peneliti lebih banyak mendengarkan cerita informan tanpa memasukkan 
asumsi pribadi sehingga data yang diperoleh bersifat apa adanya sesuai dengan apa yang disampaikan oleh informan selama sesi tanya jawab.

Paradigma konstruktivisme memandang bahasa sebagai suatu makna yang ingin disampaikan oleh komunikan (Ardianto dan Anees, 2007) di mana bahasa tidak sekadar berfungsi sebagai alat dalam menyampaikan pesan saja. Bahasa menjadi sebuah makna yang coba diungkapkan penuturnya. Karena itulah, peneliti berusaha untuk menafsirkan makna tersirat dalam penggunaan bahasa Korea (Hangeul) pengguna Instagram sebagai bentuk presentasi diri tertentu di panggung depan. Pendekatan dramaturgi ini digunakan karena ada tiga wilayah yang ingin diteliti: (1) ketika informan sedang mengekspresikan dirinya pada front stage dengan menggunakan bahasa Korea (Hangeul); (2) bagaimana bagaimana informan mempersiapkan dirinya sebelum tampil di Instagram; (3) sewaktu sedang tidak menggunakan Instagram dan menjalankan aktivitas di kehidupan nyata.

Dalam proses perolehan data, peneliti melakukan wawancara mendalam kepada lima informan pengguna aktif Hangeul yang juga mempelajari Hangeul secara mandiri (otodidak). Peneliti juga melakukan pengamatan terhadap akun-akun Instagram para informan dan studi dokumentasi terhadap berbagai literatur-literatur terkait yang dapat menguatkan penelitian ini. Teknis analisis data yang digunakan adalah analisis interaktif Miles-Huberman (dalam Prastowo 2012).

\section{HASIL DAN PEMBAHASAN}

Penelitian ini berfokus pada presentasi diri yang terbentuk melalui penggunaan Hangeul dalam Instagram. Menurut Erving Goffman (dalam Saraswati, 2017), manusia mempelajari bagaimana cara bermain peran dan mengasumsikan identitasnya dengan peran-peran tersebut, dan hal ini dilakukan dengan terlibat dalam kegiatan pertunjukkan akan siapa dan apa yang mereka perankan. Sebab itu, presentasi diri seseorang bertujuan untuk membentuk situasi dan identitas sosial untuk diri tersebut. Berdasarkan pada hasil penelitian, ditemukan bahwa kelima informan mencoba untuk menyesuaikan sisi mana yang harus ditunjukan untuk menciptakan identitas tertentu dari kesan yang bisa mereka ciptakan di benak pengikut akun Instagram mereka.

Cara mereka menciptakan identitas tersebut adalah dengan menunjukkan kemampuan Hangeul mereka melalui penulisan caption, berkomentar serta menulis bio Instagram mereka. Selain memiliki ekspektasi tersendiri terkait kesan dan identitas yang ingin diciptakan, antara lain sebagai orang yang multilingual (menguasai banyak bahasa asing), orang yang mempunyai ketertarikan terhadap budaya Korea, mirip dengan orang asli Korea, serta bisa mendapat feedback positif dari kegiatan menggemari (fan girling) idola asal Korea. 
Presentasi diri adalah upaya seseorang membentuk kesan ketika sedang berhadapan dengan orang lain. Kesan itu dapat dibentuk dengan menata perilakunya sedemikian rupa agar orang lain mampu memaknai identitas dirinya sesuai dengan apa yang ia inginkan. Selama proses produksi identitas tersebut, seseorang akan melakukan banyak pertimbangan terhadap atribut yang digunakan, di mana atribut yang ia gunakan harus sesuai, mendukung kesan dan identitas yang ingin ditampilkannya secara utuh dan menyeluruh.

Peneliti juga menemukan bahwa terdapat usaha-usaha tersendiri yang dilakukan lima informan untuk bisa membentuk kesan yang telah disebutkan sebelumnya. Kelima informan juga melakukan penataan terdahulu sebelum menulis Hangeul di Instagram. Mereka juga memiliki pertimbangan dan kriteria tersendiri tentang unggahan seperti apa yang dirasa sesuai guna diberikan caption menggunakan Hangeul. Sementara itu, semua informan memiliki kriteria yang sama saat memberikan caption menggunakan Hangeul ketika unggahan tersebut berhubungan dengan Korea, misalnya ketika sedang berwisata ke Korea, aktivitas fan girling seperti mengunggah foto atau video idola mereka, sedang bersama komunitas penggemar Korea, dan ketika merasa unggahan tersebut cocok jika diberikan caption dengan menggunakan frasa bahasa Korea.

Mulyana (2001) menjelaskan bahwa di panggung depan, aktor akan memberikan sebuah konsep idealis yang penuh polesan untuk memberikan kesan sebaik mungkin terhadap peran yang ia mainkan. Hal ini pun dilakukan oleh kelima informan penelitian, di mana mereka menjadikan akun Instagram mereka sebagai sebuah panggung depan. Pada panggung ini, mereka mencoba untuk menampilkan pertunjukkan supaya mampu merealisasikan kesan dan identitas yang mereka harapkan seperti yang telah dipaparkan sebelumnya. Para informan merasa bahwa pembentukan kesan di Instagram menjadi hal penting, di mana apa pun yang dilakukan oleh mereka di Instagram akan menjadi tolok ukur menyangkut sebaik apa kesan yang akan muncul di dalam benak pengikut mereka.

Adapun pertunjukan yang mereka tampilkan adalah menggunakan bahasa Korea (Hangeul) dalam aktivitas Instagram seperti menulis caption untuk foto atau video yang diunggah, memberikan komentar dan menulis bio. Berdasarkan hasil penelitian, kelima informan mengungkapkan hal serupa, yakni mereka berusaha untuk dapat menciptakan kesan dan identitas melalui penggunaan Hangeul di Instagram mereka.

Para informan juga beranggapan penggunaan bahasa dalam Instagram merupakan aspek yang penting dan perlu diperhatikan. Bahasa menjadi alat untuk mendeskripsikan maksud yang lebih mendalam mengenai unggahan para informan yang kemudian memperkuat kesan yang tercipta pada ingatan para pengikut mereka. Bahasa yang digunakan juga akan menjadi salah satu aspek self-branding para pengguna dalam menampilkan identitas diri mereka 
melalui akun Instagram mereka. Hal ini semakin mendukung motif mereka menggunakan Hangeul untuk menguatkan kesan yang akan muncul dalam ingatan pengikut mereka.

Hasil penelitian juga menunjukkan bahwa informan memiliki panggung tengah mereka sendiri, di mana mereka mempersiapkan hal-hal yang mampu mengoptimalkan permainan peran mereka di panggung depan. Di panggung tengah, informan mengaku terkadang merasa ragu ketika akan menulis Hangeul di Instagram. Namun, mereka juga memiliki cara tersendiri untuk mengatasi keraguan tersebut. Para informan menjelaskan bahwa mereka selalu mengetik Hangeul menggunakan fitur keyboard yang tersedia di telepon genggamnya, terutama untuk memperlihatkan bahwa mereka sudah memiliki kemampuan yang baik untuk menulis Hangeul secara langsung tanpa memanfaatkan media translasi.

Ketika berada di panggung depan, para informan kerap kali menggunakan Hangeul pada unggahan Instagram mereka sebagai aksi penbentukan kesan diri mereka terhadap pengikut. Namun, dari kelima informan, hanya empat di antaranya yang menggunakan bahasa Korea dalam percakapan sehari-hari di kehidupan nyata. Mereka mengemukakan bahwa terkadang bahasa Korea secara otomatis mereka gunakan apabila mereka merasa bingung untuk mengungkapkan sesuatu dalam bahasa Indonesia atau Inggris. Informan juga mengatakan bahwa terdapat perbedaan sisi diri yang ditampilkan saat di Instagram dan kehidupan nyata. Di Instagram, mereka hanya menampilkan momen-momen yang menyenangkan dan menjaga perilaku, karena apa yang diperlihatkan melalui Instagram akan menjadi bagian dari aspek self branding.

Ketika memutuskan untuk mempelajari Hangeul secara mandiri (otodidak), para informan kurang lebih memiliki alasan yang sama, yaitu karena merasa tertarik dengan dunia hiburan dan budaya Korea. Para informan mempelajari huruf Hangeul terlebih dahulu, baik dari cara penulisannya maupun cara membacanya; setelah menguasai huruf Hangeul, mereka kemudian mendalami tata bahasa dan penataan kalimat dalam bahasa Korea. Dalam mempelajari Hangeul, kelima informan menjelaskan mereka mempelajari Hangeul melalui media internet dan YouTube. Dua informan penelitian menjelaskan bahwa mereka memiliki situs spesifik untuk mendalami Hangeul: talktomeinkorean.com dan howtostudykorean.com. Sementara tiga yang informan lainnya menjelaskan bahwa selama mempelajari Hangeul mereka belajar melalui situs-situs yang muncul sebagai hasil pencarian di Google dan tak ada situs yang spesifik. Mereka hanya memilih untuk belajar dari situs yang dianggapnya lebih mudah untuk dimengerti.

Penggunaan Hangeul pada aktivitas Instagram mereka menunjukkan bahwa para informan memiliki harapan tersendiri akan seperti apa orang memandang mereka. Dua di antaranya menjelaskan mereka ingin dipandang sebagai orang mengagumkan karena bisa berbahasa 
asing (bahasa Korea). Mereka juga hendak menunjukkan identitas diri mereka sebagai penggemar dunia hiburan Korea. Dua informan lainnya mempunyai harapan yang berbeda, terutama mereka ingin menunjukkan bahwa kegiatan fan girling yang mereka lakukan selama ini bukan kegiatan yang negatif seperti asumsi kebanyakan orang. Menurut mereka, kegiatan fan girling yang selama ini dilakukan mendatangkan banyak sisi positif dan menguntungkan, seperti ia menjadi kenal dengan budaya negara Korea, mahir berbahasa Korea dan bahkan memiliki banyak teman-teman yang berasal dari Korea. Sementara itu, satu informan lainnya menjelaskan jika ia ingin dianggap mirip orang Korea asli. Karena itu, ia sangat memperhatikan penataan unggahan pada profilnya agar terlihat rapi dan mampu memberikan kesan Korea. la menambahkan bahwa penggunaan Hangeul yang ia gunakan untuk menulis keterangan nama, menulis caption, berkomentar di Instagram juga turut dilakukan untuk memunculkan kesan tersebut, karena dengan menampilkan kemampuannya untuk berbahasa Korea akan semakin menguatkan kesan yang tercipta pada benak para pengikut akun Instagramnya.

Kemampuan informan dalam menguasai Hangeul tentunya mendatangkan keuntungan tersendiri bagi mereka. Lima informan merasa bahwasanya mempelajari Hangeul dapat memperluas wawasan, semakin mengenal kebudayaan Korea, mempermudah saat menonton tayangan Korea tanpa mengandalkan terjemahan, mempermudah perjalanan ketika berwisata ke Korea, dan bisa mendatangkan teman-teman baru dari Korea. Salah satu informan bahkan menjelaskan bagaimana penguasaannya terhadap Hangeul telah menjadikannya memiliki kemampuan untuk bekerja sebagai freelance interpreter antara perusahaan Korea dengan Indonesia.

Kelima informan menjelaskan bahwa mereka mendapatkan reaksi yang beragam ketika menggunakan Hangeul di Instagram; kebanyakan reaksinya adalah positif berupa pujian terkait kemampuan Hangeul mereka yang cukup baik. Untuk mendapatkan reaksi tertentu, kelima informan akan mencoba untuk menggunakan Hangeul dengan sesering mungkin pada aktivitas Instagramnya. Para informan menjelaskan bahwa mereka sering mendapatkan pujian terkait kemampuan Hangeul mereka atau banyak yang menanyakan bagaimana cara menguasai Hangeul dan media apa yang bisa digunakan. Dua informan bahkan mengatakan bahwa mereka sering mendapat respon positif dari teman-temannya yang juga penggemar drama Korea namun tidak memiliki kemampuan Hangeul karena mampu menonton tayangan Korea tanpa menunggu subtitle yang disediakan oleh orang lain. Tak hanya itu, bahkan kelima informan mengaku sering mendapatkan pujian dari orang Korea asli terkait kemampuan Hangeul mereka yang dianggap sangat baik untuk kategori orang asing. Salah satu informan menceritakan bahwa orang asli Korea kadang masih memandang skeptis terhadap orang asing yang menggemari dunia hiburan dan kebudayaan Korea; mereka beranggapan bahwa 
orang-orang tersebut hanya menyukai secara sekilas saja, tidak sampai mempelajari bahasa Korea. Karena itu, mereka kagum apabila ada orang asing yang mahir berbahasa Korea, bahkan sampai paham tata bahasa dan penataan kalimat dalam bahasa Korea.

\section{KESIMPULAN}

Instagram menjadi panggung depan bagi lima informan dalam menampilkan diri mereka dengan menggunakan bahasa Korea (Hangeul); penggunaannya antara lain bisa untuk menulis caption untuk foto atau video yang diunggah, memberikan komentar dan menulis bio. Dalam mempersiapkan peran yang akan mereka tampilkan, pada panggung tengah mereka menjelaskan bahwa mereka selalu mengetik Hangeul menggunakan fitur keyboard yang tersedia di telepon genggam. Hal ini menunjukkan bahwa mereka sudah memiliki kemampuan yang cukup baik untuk dapat menulis Hangeul secara langsung tanpa memanfaatkan media translasi. Di panggung belakang atau kehidupan sehari-hari, terdapat perbedaan sisi diri yang ditampilkan ketika di Instagram dan kehidupan nyata. Di Instagram mereka hanya menampilkan momen-momen yang menyenangkan saja dan mereka lebih menjaga perilaku, karena apa pun yang diperlihatkan akan menjadi bagian dari aspek self branding.

Ketika memutuskan untuk mempelajari Hangeul secara mandiri (otodidak), para informan kurang lebih mempunyai alasan yang sama yaitu merasa tertarik dengan dunia hiburan dan budaya Korea. Dalam mempelajari Hangeul, kelima informan menjelaskan bahwa mereka mempelajari Hangeul lewat media internet dan YouTube. Selama proses belajar, para informan juga memiliki kesulitan seperti sulitnya menyesuaikan lidah agar dapat memiliki pelafalan, sulit mengatur waktu, mengumpulkan niat dan semangat serta tata bahasa dan penataan kalimat dalam bahasa Korea yang rumit. Dalam menggunakan Hangeul di Instagram, para informan mempunyai harapan serta ekspektasi, seperti ingin dipandang sebagai orang yang mengagumkan karena memiliki kemampuan berbahasa asing (Korea), ingin menunjukkan identitas diri bahwa mereka adalah penggemar dunia hiburan Korea, ingin memperlihatkan bahwa kegiatan fan girling mampu mendatangkan banyak sisi yang positif dan menguntungkan, dan ingin dilihat sebagai orang yang mirip orang Korea. Para informan juga menjelaskan bahwa mereka sering mendapatkan reaksi positif berupa pujian terkait kemampuan Hangeul yang dapat dikatakan baik. Beberapa informan bahkan menceritakan bahwa mereka pernah mendapat pujian serta merasakan apresiasi dari orang Korea asli. 


\section{REFERENSI}

Ainslie, M. (2016). "K-dramas across Thailand: Constructions of Koreanness and Thainess by Contemporary Thai Consumers". The Asia-Pacific Journal, 14(7): 1-13.

Aisyah, Aznur. (2017). "Korean-English Language Translational Action of K-Pop Social Media Content: A Case Study on Bangtan Sonyeondan's (BTS) Official Twitter". The Southeast Asian Journal of English Language Studies, 23(3): 67-80.

Al-Kandari, Ali A., Fahad Y. Al-Sumait \& Ahmed Al-Hunaiyyan. (2017). "Looking Perfect: Instagram Use in a Kuwaiti Cultural Contex". Journal of International and Intercultural Communication, 10(4): 273-290.

Al-Kandari, Ali, Srinivas R. Melkote and Ahmad Sharif. (2016). "Needs and Motives Of Instagram Users that Predict Self-Disclosure Use: A Case Study of Young Adults in Kuwait". Journal of Creative Communications, 11(2): 85-101.

Ardianto, Elvinaro. \& Bambang Q-Anees. (2007). Filsafat Ilmu Komunikasi. Bandung: Simbiosa Rekatama Media.

Bae, Eun-song, Meehyang Chang, Eung-Suk Park and Dae-cheol Kim. (2017). "The Effect of Hallyu on Tourism in Korea". Journal of Open Innovation, 3(22): 1-12.

Bazarova, Natalya N. and Yoon Hyung Choi. (2014). "Self-Disclosure in Social Media: Extending Functional Approach to Disclosure Motivations and Characteristics on Social Network Sites". Journal of Communication, 64(4): 635-657.

Cresswell, J. W. (2004). Research Design: Qualitative, Quantitative and Method Approached. California: Sage Publication.

Dator, Jim and Yongseok Seo. (2004). "Korea as The Wave of a Future: The Emerging Dream Society of Icons and Aesthetic Experience". Journal of Futures Studies, 9(1): 31-44.

Goffman, E. (1959). The Presentation of Self in Everyday Life. New York: Doubleday.

Hayutami, R. (2012). Campur Kode pada Siswa TK RA Kartini Temanggung. Skripsi: Universitas Negeri Yogyakarta.

Hidayat, D. H. (2003). Paradigma dan Metodologi Penelitian Sosial Empirik Klasik. Depok: Departemen Ilmu Komunikasi FISIP Universitas Indonesia.

Hong, Soonkwan and Chang-Ho Kim. (2013). "Surfing Korean Wave: A Postcolonial Critique of The Mythologized Middlebrow Consumer Culture in Asia". Qualitative Market Research: An International Journal, 16(1): 53-75.

Huang, Shuling. (2017). "Social Media and the New Korean Wave". Media Culture \& Society, 39(5): 773-777.

Hwang, Ha Sung and Jaehee Cho. (2018). "Why Instagram? Intention to Continue using Instagram among Korean College Students". Social Behavior and Personality: An International Journal, 46(8): 1305-1316. 
Jeong, Jae-Seon, Seul-Hi Lee and Sang-Gil Lee. (2017). "When Indonesians Routinely Consume Korean Pop Culture: Revisiting Jakartan Fans of the Korean Drama Dae Jang Geum". International Journal of Communication, 11: 2288-2307.

Jin, Dal Y. and Tae-Jin Yoon. (2017). "'The Korean Wave: Retrospect and Prospect". International Journal of Communication, 11: 2241-2249.

Kaplan, Andreas and Michael Haenlein. (2010). "Users of the World, Unite! The Chalanges and Opportunities of Social Media", Business Horizons, 53(1): 59-68.

Kim, Gooyong. (2017). "Between Hybridity and Hegemony in K-Pop's Global Popularity: A Case of Girls' Generation's American Debut". International Journal of Communication, 11: 2367-2386.

Kusyanti, Ari dan One Safitri. (2016). "How Do I Look: Self-Disclosure of Instagram Users in Indonesia". Journal of Education and Social Sciences, 5(2): 242-247.

Meikle, G. \& Young, S. (2012). Media Convergence: Networked Digital Media in Everyday Life. London: Palgrave Macmillan.

Mulyana, D. (2001). Metode Penelitian Kualitatif. Bandung: PT. Remaja Rosdakarya.

Mulyana, D. (2008). Ilmu Komunikasi. Bandung: PT. Remaja Rosdakarya.

Nasrullah, R. (2015). Media Sosial Perspektif Komunikasi, Budaya dan Sosioteknologi. Bandung: Simbiosa Rekatama Media.

Peichi, C. (2013). "Co-creating Korean Wave in Southeast Asia: Digital convergence and Asia's Media Regionalization". Journal of Creative Communications, 8(2/3): 193-208.

Prastowo, Andi. (2012). Metode Penelitian Kualitatif dalam Perspektif Rancangan Penelitian. Yogyakarta: Ar-ruzzmedia.

Saraswati, A. R. (2017). Presentasi Diri Melalui Media Sosial Snapchat (Studi Dramaturgi: Pengguna Snapchat di Kalangan Mahasiswa Universitas Telkom Bandung). Skripsi: Universitas Telkom.

Schau, Hope J. and Mary C. Gilly. (2003). "We Are What We Post? Self Presentation in Personal Web Space". Journal of Consumer Research, 30(3): 385-404.

Shim, D. (2006). "Hybridity and The Rise of Korean Popular Culture in Asia". Media, Culture \& Society, 28(1): 25-44.

Sung, Sang-Yeon. (2010). "Constructing a New Image. Hallyu in Taiwan”. European Journal of East Asian Studies, 9(1): 25-45.

Trolan, Joe. (2017). "A Look into Korean Popular Culture and Its Tourism Benefits". International Journal of Educational Policy Research and Review, 4(9): 203-209.

Vainikka, Eliisa, Elina Noppari and Janne Seppänen. (2017). “Exploring Tactics of Public Intimacy on Instagram". Participations, Journal of Audience \& Reception Studies, 14(1): 108128. 
van Dijck, J. (2013). The Culture of Connectivity: A Critical History of Social Media. Oxford: Oxford University Press.

Williamson, Patricia, et al. (2017). "Me, My 'Selfie' and I: A Survey of Self-disclosure Motivations on Social Media". IAFOR Journal of Cultural Studies, 2(2): 71-85.

(c) (i) (2) Copyright (c) 2019 Nyimak Journal of Communication

This work is licensed under aCreative Commons Attribution-ShareAlike 4.0 
